\title{
AZ ASTHMA BRONCHIALE ÉS BIOLÓGIAI KEZELÉSE
}

\section{ASTHMA AND ITS BIOLOGICAL TREATMENT}

\author{
Horváth Ildikón ${ }^{1,2}$, Csoma Zsuzsanna ${ }^{1,3}$, Kovács Gábor (levelező szerző) ${ }^{1,4}$ \\ 'Országos Korányi Pulmonológiai Intézet, Budapest \\ 2az MTA doktora, egyetemi tanár, orvosigazgató, igazgatosag@koranyi.hu \\ ${ }^{3} \mathrm{PhD}$, járóbeteg-ellátást vezető főorvos \\ 4fóigazgató főorvos, igazgatosag@koranyi.hu
}

\begin{abstract}
ÖSSZEFOGLALÁS
Az asztma közel 350 millió embert érint a világon, a legnagyobb kihívást a betegek 5-10\%-át érintő súlyos asztma jelenti. A biológiai gyógyszereknek a fejlesztése ezen a területen hozott áttörő eredményeket. Súlyos allergiás asztmában évek óta használatban van az immunglobulin $\mathrm{E}$ elleni antitest, és a súlyos eozinofilsejtes asztmában ma már több molekula is elérhető, amelyek a 2. típusú immunitás citokinjeit vagy azok receptorát támadják. Ezek a gyógyszerek csökkentve állapotrosszabbodásaik számát és szisztémás szteroid igényüket, hatékonyan javítják a betegek állapotát. A súlyos asztma kezelése így egyre inkább személyre szabható. A jelen összefoglalóban a szerzők áttekintik a súlyos asztma kezelésében használt biológiai szereket és a terület új fejlesztési irányait.
\end{abstract}

\section{ABSTRACT}

Asthma affects almost 350 million people worldwide, the disease burden is the highest in that $5-10 \%$ of asthmatics who suffer from severe asthma. Biological treatment options have gained position in this severely affected patient group. Their development has occurred together with better understanding of the pathomechanism and the development of biomarkers for disease phenotyping. These improvements led to new drugs available for the treatment of severe allergic asthma and severe eozinofilic asthma. Monoclonal antibodies against different pathways has led to improvement in disease control by decreasing the number of asthma exacerbations and resulting in decreased need for systemic steroids. This approaches have paved the way for more personalised treatment approach in this disease. We review the currently available biologics for severe asthma together with the new developments.

Kulcsszavak: súlyos asztma, eozinofilsejt, antitest, szisztémás szteroid, biológiai kezelés

Keywords: severe asthma, eosinophils, antibody, systemic steroid, biological therapy 


\section{AZ ASTHMA BRONCHIALE KLINIKAI MEGJELENÉSE, PATOGENETIKÁJA}

Az asthma bronchiale gyakori, sokszor gyermekkorban kezdődő minden életkort érintő krónikus megbetegedés. A betegség ismétlődő, spontán vagy gyógyszerre rendeződő nehézlégzéssel, fulladással, köhögéssel, sípolással-búgással jellemezhető. Népegészségügyi jelentőségét a betegek nagy száma, a betegségben eltöltött életévek, a tanulásból és munkából való kiesés, valamint a betegség által okozott munkaképesség-csökkenés jelenti. A világon mintegy 334 millió ember szenved asztmában. Általában jól kezelhető, mégis évente közel fél millió ember halálát okozza (naponta kb. 1300 ember hal meg miatta). A betegek 5-10\%-ában kezelés mellett sem lehet kontrollt elérni, amikor ún. súlyos asztma áll fenn (Reddel et al., 2015; Csoma et al., 2011; Chung et al., 2013).

A patogenezisben genetikai tényezök és környezeti hatások egyaránt szerepet játszanak. Utóbbiak közül jelentős az allergének és a vírusinfekciók szerepe, de nem elhanyagolható a dohányzásé, illetve egyéb por-, füst- és gázártalmaké sem. A betegség tüneteinek hátterében a bronchokonstrikció, fokozott nyáktermelés és a légutak falában zajló krónikus gyulladás áll (1. ábra). A légúti gyulladást két csoportba soroljuk: a 2. és a nem 2. típusú gyulladás. A 2. típusú gyulladással jellemzett endotípusban emelkedett a köpet eozinofilsejt száma, két alcsoportja a korai kezdetű atópiás és a késői kezdetü, nem atópiás fenotípus. A késői eozinofilsejtes asztma jellegzetességeit a fix légúti obstrukció, krónikus rinoszinuszitisz, orrpolipózis, aszpirinszenzitivitás és a perifériás vér eozinofilsejt számának emelkedése, gyakori exacerbációk és szisztémás szteroid függőség, valamint a

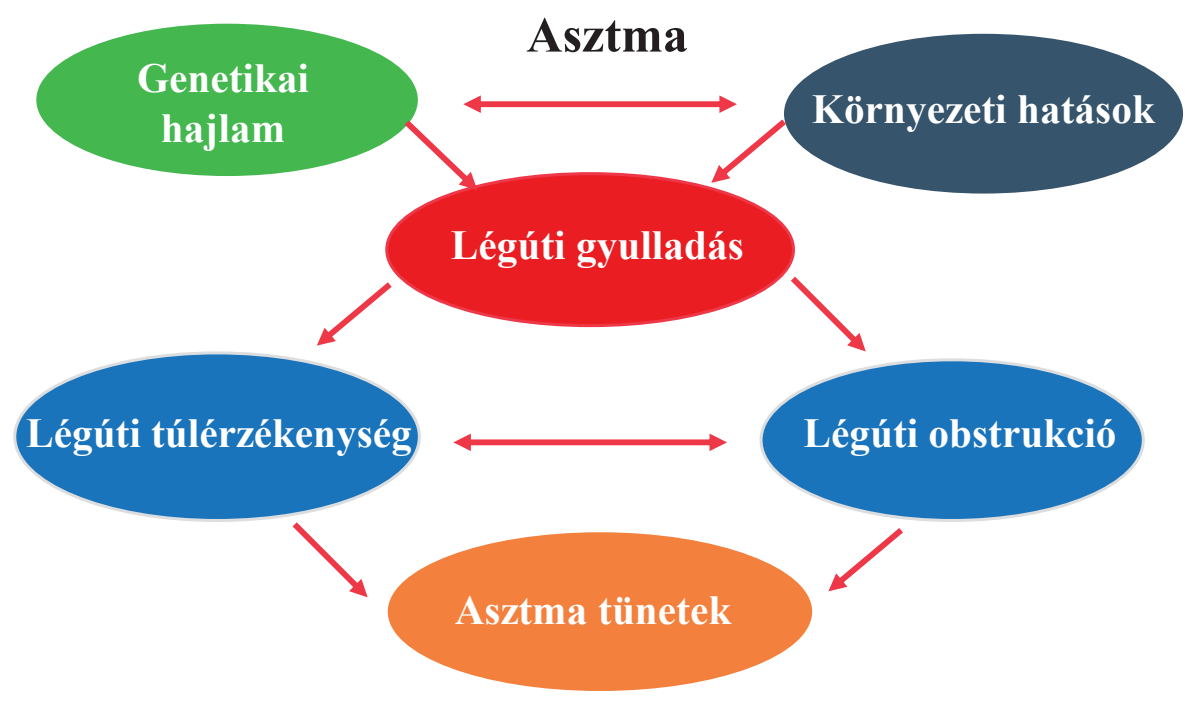

1. ábra. Az asztma patomechanizmusának kulcsfolyamatai (saját szerkesztés) 
magas kilégzett nitrogén-monoxid-koncentráció alkotja (Horváth et al., 2017). A nem 2. típusú endotípust a köpet-neutrofilsejtek túlsúlya, az atópia hiánya, alacsony légzésfunkciós mutatók, súlyos légúti szűkület és bakteriális infekciók jellemzik (T17-es endotípus). A neutrofilsejtes asztmában a légúti mikrobiom és a különböző bakteriális, virális fertőzés kóroki szerepét és a társuló immunológiai szabályozási zavart vizsgálják. Előfordul kevert típus és olyan is, amelyben nem vagy alig található gyulladásos sejt a légutakban (Shaw et al., 2015).

\section{A PATOGENEZISBEN FELDERITETT TERÁPIÁS CÉLPONTOK, TERÁPIÁS LEHETŐSÉGEK}

A lokálisan alkalmazott (inhalált) kortikoszteroid terápia monoterápiaként vagy hosszú hatású $\beta 2$ adrenerg receptor agonistákkal kombinálva az asztmakezelés sarokkövét jelenti. A másik kontrolláló szer a leukotrién antagonista. A tartós nagy dózisú inhalációs szteroid és még egy kontrolláló szer mellett is panaszos betegek, vagy akiknek ennél intenzívebb kezelésre van szükségük a kontroll eléréséhez (például tartós szisztémás szteroid) a súlyos asztmások csoportját képezik. Közöttük halmozódik a kórházi bent fekvések és a táppénzes napok száma, a munkából való kiesés, az asztma miatti munkaképesség-csökkenés, és gyakori a szisztémás szteroidok miatti mellékhatás (Csoma et al., 2011; Chung et al., 2013). A patogenetikában azonosított molekuláris útvonalakban több gyógyszercélpontot azonosítottak, melyekre sikerült megfelelö biológiai szereket kifejleszteni (Godar et al., 2018). A főbb hatóanyagokat a 2. ábra foglalja össze.

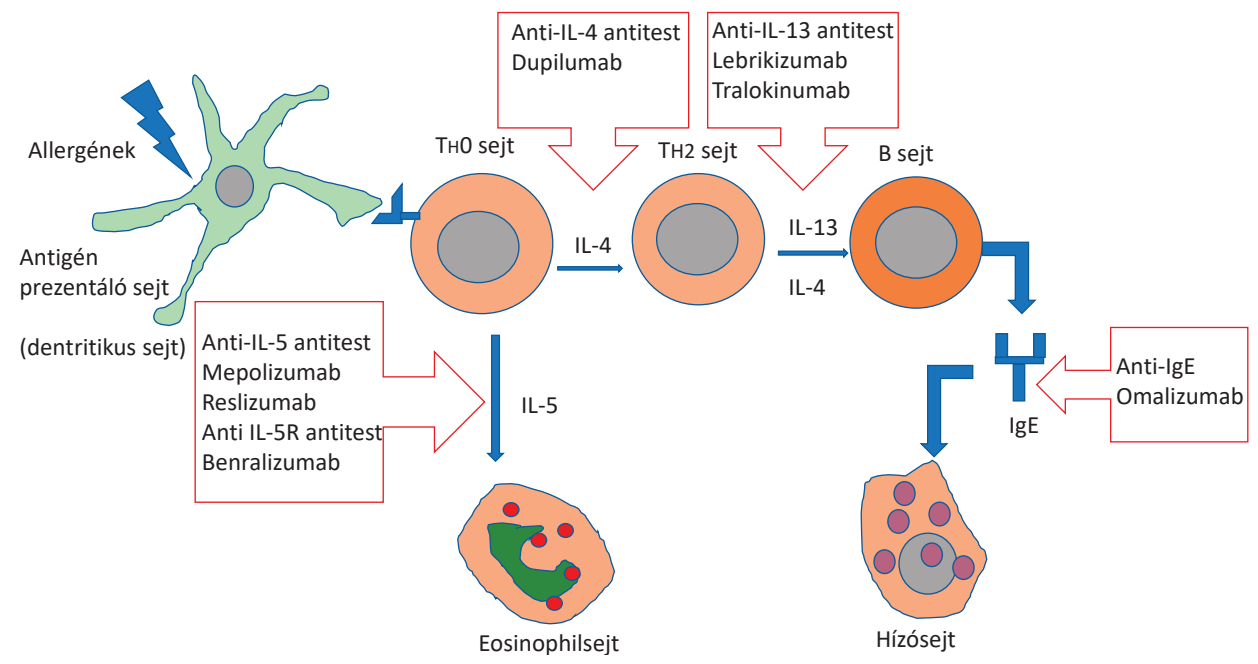

2. ábra. A T2 asztmás légúti gyulladás biológiai kezelésének célpontjai, hatóanyagai (saját szerkesztés) 


\section{IMMUNGLOBULIN E (IGE) ELLENI GYÓGYSZEREK}

A súlyos asztma kezelésében elsőként használt biológiai szer az immunglobulin E (IgE) elleni monoklonális antitest, az omalizumab volt. A gyógyszer alkalmazása az allergiás fenotípuson és egy biomarkeren, az IgE-szinten alapul. Prediktív biomarker nem ismert, a kezelés hatékonyságát utólagosan lehet csak értékelni. A gyógyszer csökkenti az asztmás állapotrosszabbodások gyakoriságát, a kórházi ápolások számát és a szteroidigényt (Normansell et al., 2014). Friss publikáció igazolta tartós alkalmazásának biztonságosságát, de továbbra sem eldöntött kérdés a kezelés optimális időtartama.

\section{INTERLEUKIN-5 (IL-5) ELLENI GYÓGYSZEREK}

Az interleukin-5 (IL-5) citokin az eozinofilsejtek termelödésében, légutakba való migrációjában központi szerepü. A mepolizumab, egy humanizált monoklonális IL-5 elleni antitest, amely súlyos eozinofilsejtes asztmában a perifériás vér eozinofilsejt számának jelentős csökkentése mellett kb. felére redukálja az exacerbációk számát, és szintén csökkenti a szisztémás szteroid szükségletet. A fenti mutatókban hasonló kedvező hatása van a reslizumab (humanizált $\operatorname{IgG}_{4}$ monoklonális IL-5 elleni antitest) és a benrolizumab (humanizált monoklonális IL-5 receptor- $\alpha$ elleni antitest) kezelésnek is. A Cochrane-elemzés alapján az anti-IL5 terápia hatékony kiegészítője a hagyományos kezelésnek a súlyos asztmások eozinofilsejtes fenotípusában (Farne et al., 2017). Hosszú távú direkt összehasonlító vizsgálatok szükségesek a három készítmény klinikai hatékonyságának, mellékhatás profiljának, hosszú távú biztonságosságának pontos összevetésére.

A betegek egy része az anti-IgE és anti-IL-5 terápiákra egyaránt alkalmas, és jelenleg nincs megfelelő biomarker, ami segítene dönteni a terápiaválasztásban. A hazai irányelv arra tesz javaslatot, hogy a domináló fenotípust vegyék figyelembe.

\section{INTERLEUKIN-4 ÉS INTERLEUKIN-13 ELLENI GYÓGYSZEREK}

A dupilumab az IL-4 receptor- $\alpha$ elleni monoklonális antitest, és közösen gátolja az IL-4-et és az IL-13-at. Klinikai vizsgálatokban a szisztémás szteroid dózisát és az exacerbációk számának jelentős csökkenését lehetett elérni a kezelés dupilumabbal történő kiegészítésével súlyos eozinofilsejtes asztmában (Drazen-Harrington, 2018). A lebrikizumab és a tralokinumab humanizált monoklonális IL-13 elleni $\mathrm{IgG}_{4}$ antitestek, melyek az IL-13 funkciókat gátolják. Klinikai vizsgálatok folynak a két gyógyszerrel kapcsolatosan. 


\section{EGYÉB (PRE) BIOLÓGIAI SZEREK ASZTMÁBAN}

A fevipiprant egy szájon át tablettaként alkalmazható hatóanyag az asztma kezelésére. A gyulladásos és a strukturális sejteken levő prosztaglandin D2 receptor 2 gátlásával fejti ki hatását. A molekula vizsgálatára már elvégezték a fázis 2 . vizsgálatokat, a fázis 3 . vizsgálat folyamatban van. Ezek sikere esetén a súlyos asztma kezelési lehetőségeinek bővülése új szakaszba léphet.

Elsősorban a nem T2 gyulladást mutató asztmásokat célozta a tumornekrózisfaktor (TNF)- $\alpha$ antagonista golimumab, amelyet azonban a klinikai vizsgálata során észlelt mellékhatások miatt asztma kezelésre nem engedélyeztek (Wenzel et al., 2009). A tumornekrózisfaktor szuperfamíliát befolyásoló molekulákkal ígéretes eredmények vannak. Ezek, illetve az anti-IL-17 hatóanyagok hatékonysága esetén megnyílna a nem T2 gyulladásos asztma kezelési lehetősége. Ezen túlmenően az anti-T2 és az anti-T17 hatóanyagok kombinációjától a súlyos asztmában észlelt immun diszreguláció jelentős javulása várható, ha a kombináció mellékhatás profilja megfelelő lesz. Ilyen, a T2 és nem T2 típusú asztma endotípusban egyaránt klinikai hatást mutatott tezepelumab, amely függetlenül az asztmás légúti gyulladás celluláris endotípusától, jelentősen gátolja az exacerbációk számát, és javítja a betegek állapotát.

Az immunregulációt más ponton befolyásoló szerek vizsgálata is folyik súlyos asztmával kapcsolatosan (például a programozott sejthalállal kapcsolatos antitestek).

\section{MAGYARORSZÁGON REGISZTRÁLT ÉS FINANSZÍROZOTT BIOLÓGIAI GYÓGYSZEREK}

Hazánkban a biológiai szerek közül 2005 óta engedélyezett és forgalomban van az omalizumab. Az omalizumab alkalmazásának szabályait az 31/2010. (V. 13.) EüM rendelet tartalmazza. Az emelt, kiemelt indikációhoz kötött támogatási kategóriába tartozó betegségcsoportok, indikációs területek és a felírásra jogosultak körében rögzített a finanszírozás feltételrendszere és a kijelölt intézmények köre.

A mepolizumab 2015 óta engedélyezett, és 2016-ban került regisztrálásra a reslizumab. Az omalizumab felírhatóságához hasonló módon jelenleg már mindkét készítmény $100 \%$-os támogatással érhető el a betegek számára. A benralizumab engedélyezése 2018. januári dátummal szerepel az OGYÉI honlapján, befogadása a társadalombiztosítási finanszírozásba folyamatban van.

\section{A HAZAI ELLÁTÓ STRUKTÚRA, KEZELT BETEGEK SZÁMA}

Az asthma bronchiale ellátása hazánkban döntően a tüdőgyógyász-hálózatban zajlik. A szakorvosi javaslat alapján a háziorvos egy évig írhatja fel emelt támogatással az asztma kezeléséhez szükséges gyógyszereket. A 2018. évi Korányi 
Bulletin adatai alapján 300 ezer körüli asztmás beteget gondoztak a tüdőgondozókban. A többi beteg (a nemzetközi adatokra támaszkodó becslések szerint kb. 400-600 ezer fö) vagy nem fordul orvoshoz tüneteivel, vagy az alapellátásban vagy más szakorvosoknál kap kezelést. A súlyos asztma kb. 10-20 ezer beteget érint. A biológiai kezelésére központok kerültek kijelölésre. Kihívást jelent, hogy a háziorvosok és a tüdőgondozó-hálózatban dolgozó kollégák felismerjék a súlyos asztmás betegeiket, és a központokba irányítsák őket, hogy korszerü terápiához juthassanak. Ez az ellátók és a betegek szakmai képzését igényli, mert a biológiai kezelésre alkalmas 2-5 ezres becsült beteganyaghoz képest ennek csak kb. 10\%-a kap biológiai kezelést. Jelenleg egy-kétszáz között van az omalizumabbal kezelt súlyos asztmások száma, és kevesebb mint száz súlyos asztmás kap IL-5 gátló kezelést.

A központosított szerkezet a minőségbiztosítás szempontjából megfelelő választás, azonban nehezíti a betegek gyógyszerhez való hozzáférését. Mérlegelhető az intézményi kör bővítése a betegek közelében levő tüdőgyógyászati rendelések és a megyei tüdőgyógyászati osztályok irányába. Mivel vannak ez irányú, más országból származó tapasztalatok, továbbá a benralizumab és mepolizumab otthoni alkalmazásával is történtek vizsgálatok (Ferguson et al., 2018; Bel et al., 2019), az ilyen irányú előrelépés biztonságossága megfelelőnek látszik. Az első lépések ebbe az irányba már meg is történtek.

Összefoglalva, az asztma kezelésében a biológiai terápiák jelentősen javítják a súlyos betegek állapotát, csökkentik a szisztémás szteroid igényét és így annak mellékhatásait. További kutatások szükségesek ahhoz, hogy még hatékonyabb és a betegek teljes körét érintő előrelépések történjenek.

\section{IRODALOM}

Bel, E. H. - Bernstein, D. I. - Bjermer, L. et al. (2019): Usability of Mepolizumab Single-use Prefilled Syringe for Patient Self-administration. Journal of Asthma, 24, 1-10. DOI: 10.1080/02770903.2019.1604745, https://www.tandfonline.com/doi/full/10.1080/02770903.201 9.1604745

Chung, K. F. - Wenzel, S. E. - Brozek, J. L. et al. (2013): International ERS/ATS Guidelines on Definition, Evaluation and Treatment of Severe Asthma. European Respiratory Journal, 43, 343-373. DOI: 10.1183/09031936.00202013, https://erj.ersjournals.com/content/43/2/343. long

Csoma Zs. - Antus B. - Barta I. et al. (2011): A súlyos asztma hazai előfordulása és klinikai fenotipizálása. Medicina Thoracalis, 64, 313-325.

Drazen, J. M. - Harrington, D. (2018): New Biologics for Asthma. The New England Journal of Medicine, 378, 2533-2534. DOI: 10.1056/NEJMe1806037

Farne, H. A. - Wilson, A. - Powel, C. et al. (2017): Anti-IL5 Therapies for Asthma. Cochrane Database Systemic Review, 9, CD010834. DOI: 10.1002/14651858.CD010834.pub3, https://www. cochranelibrary.com/cdsr/doi/10.1002/14651858.CD010834.pub3/full 
Ferguson, G. T. - Mansur, A. H. - Jacobs, J. S. et al. (2018): Assessment of an Accessorized Prefilled Syringe for Home-administered Benralizumab in Severe Asthma. Journal of Asthma and Allergy, 11, 63-72. https://www.dovepress.com/assessment-of-an-accessorized-pre-filledsyringe-for-home-administered-peer-reviewed-fulltext-article-JAA

Godar, M. - Blanchetot, C. - de Haard, H. et al. (2018): Personalized Medicine with Biologics for Severe Type 2 Asthma: Current Status and Future Prospects. MAbs, 10, 34-45. DOI: 10.1080/19420862.2017.1392425, https://www.tandfonline.com/doi/full/10.1080/19420862.201 7.1392425

Horváth I. - Barnes, P. J. - Loukides, S. (2017): A European Respiratory Society Technical Standard: Exhaled Biomarkers in Lung Disease. European Respiratroy Journal, 26, 49, 4, pii: 1600965. DOI: 10.1183/13993003.00965-2016, https://erj.ersjournals.com/content/erj/49/4/1600965.full. pdf

Horváth, I. - Donnelly, L. E. - Kiss, A. et al. (1998): Combined Use of Exhaled Hydrogen Peroxide and Nitric Oxide in Monitoring Asthma. American Journal of Respiratory and Critical Care Medicine, 158, 4, 1042-1046. DOI: 10.1164/ajrccm.158.4.9710091, http://citeseerx.ist.psu.edu/ viewdoc/download?doi=10.1.1.318.6899\&rep=rep1\&type $=$ pdf

Horváth I. - Dweik, R. - Barnes, P. J. (2012): Exhaled Nitric Oxide Comes of Age. Journal of Breath Research, 6, 40201. DOI: 10.1088/1752-7155/6/4/040201, https://iopscience.iop.org/article/10.1088/1752-7155/6/4/040201/pdf

Normansell, R. - Walker, S. - Milan, S. C. et al. (2014): Omalizmab for Asthma in Adults and Children. Cochrane Database Systemic Review, 1, CD003559. DOI: 10.1002/14651858.CD003559. pub4, https://www.cochranelibrary.com/cdsr/doi/10.1002/14651858.CD003559.pub4/full

Reddel, H. K. - Bateman, E. D. - Becker, A. et al. (2015): A Summary of the New GINA Strategy: A Roadmap to Asthma Control. European Respiratory Journal, 46, 622-639. https://erj. ersjournals.com/content/46/3/622.long

Shaw, D. E. - Sousa, A. R. - Fowler, S. J. et al. (2015): Clinical and Inflammatory Characteristics of the European U-BIOPRED Adult Severe Asthma Cohort. European Respiratory Journal, 46, 1308-1321. https://erj.ersjournals.com/content/46/5/1308.long

Wenzel, S. E. - Barnes, P. J. - Bleecker, E. R. et al. (2009): A Randomized, Double-Blind, Placebo-Controlled Study of Tumor Necrosis Factor-alpha Blockade in Severe Persistent Asthma. American Journal of Respiratory and Critical Care Medicine, 179, 549-558. DOI: 10.1164/rccm.200809-1512OC, https://bit.ly/2XuOfrR 